\title{
Discovery of possible mega-thrust earthquake along the Seram Trough from records of 1629 tsunami in eastern Indonesian region
}

\author{
Zac Yung-Chun Liu • Ron A. Harris
}

Received: 16 July 2012/ Accepted: 10 February 2013/Published online: 22 February 2013

(C) The Author(s) 2013. This article is published with open access at Springerlink.com

\begin{abstract}
Arthur Wichmann's "Earthquakes of the Indian Archipelago" documents several large earthquakes and tsunami throughout the Banda Arc region that can be interpreted as mega-thrust events. However, the source regions of these events are not known. One of the largest and well-documented events in the catalog is the great earthquake and tsunami affecting the Banda Islands on August 1, 1629. It caused severe damage from a 15-m tsunami that arrived at the Banda Islands about a half hour after violent shaking stopped. The earthquake was also recorded $230 \mathrm{~km}$ away in Ambon, but no tsunami is mentioned. This event was followed by at least 9 years of uncommonly frequent seismic activity in the region that tapered off with time, which can be interpreted as aftershocks. The combination of these observations indicates that the earthquake was most likely a mega-thrust event. We use an inverse modeling approach to numerically reconstruct the tsunami, which constrains the likely location and magnitude of the 1629 earthquake. Only, linear numerical models are applied due to the low resolution of bathymetry in the Banda Islands and Ambon. Therefore, we apply various wave amplification factors (1.5-4) derived from simulations of recent, well-constrained tsunami to bracket the upper and lower limits of earthquake moment magnitudes for the event. The closest major earthquake sources to the Banda Islands are the Tanimbar and Seram Troughs of the Banda subduction/collision zone. Other source regions are too far away for such a short arrival time of the tsunami after shaking. Moment magnitudes predicted by the models in order to produce a 15-m tsunami are $\mathrm{M}_{\mathrm{w}}$ of 9.8-9.2 on the Tanimbar Trough and $\mathrm{M}_{\mathrm{w}}$ 8.8-8.2 on the Seram Trough. The arrival times of these waves are $58 \mathrm{~min}$ for Tanimbar Trough and $30 \mathrm{~min}$ for Seram Trough. The model also predicts 5-m run-up for Ambon from a Tanimbar Trough source, which is inconsistent with the historical records. Ambon is mostly shielded from a wave generated by a Seram Trough source. We conclude that the most likely source of the 1629 mega-thrust earthquake is the Seram Trough. Only
\end{abstract}

Z. Y.-C. Liu ( $₫)$

Department of Geological Sciences, Brigham Young University, C371 ESC, Provo, UT 84602, USA e-mail: zacqoo@gmail.com

R. A. Harris

Department of Geological Sciences, Brigham Young University, S349 ESC, Provo, UT 84602, USA e-mail: rharris@byu.edu 
one earthquake $>\mathrm{M}_{\mathrm{w}} 8.0$ is recorded instrumentally from the eastern Indonesia region although high rates of strain $(50-80 \mathrm{~mm} / \mathrm{a})$ are measured across the Seram section of the Banda subduction zone. Enough strain has already accumulated since the last major historical event to produce an earthquake of similar size to the 1629 event. Due to the rapid population growth in coastal areas in this region, it is imperative that the most vulnerable coastal areas prepare accordingly.

Keywords Tsunami modeling · Indonesia - Banda Arc $\cdot$ Seram Trough · Tanimbar Trough $\cdot$ Banda Islands · Ambon · Mega-thrust earthquakes

\section{Introduction}

During the twentieth century, Indonesia had around two hundred major earthquakes $\left(\mathrm{M}_{\mathrm{s}}\right.$ 7.5 or greater), more than all of North America or South America during the same time interval (Harris et al. 1997). At least 110 of these earthquakes were destructive; the majority jolting densely populated western Indonesia (Fig. 1).

These high rates of seismic activity in the past century are consistent with the recorded history of Indonesia, as documented in a compilation of geophysical events from the seventeenth to nineteenth centuries by Wichmann (1918). The reliability of the earthquake and tsunami catalog is demonstrated by the recent recurrence of several earthquakes that ruptured similar fault segments and are of similar magnitudes to those inferred from earlier accounts. For example, the 2005 northern Sumatra earthquake near Nias Island ruptured

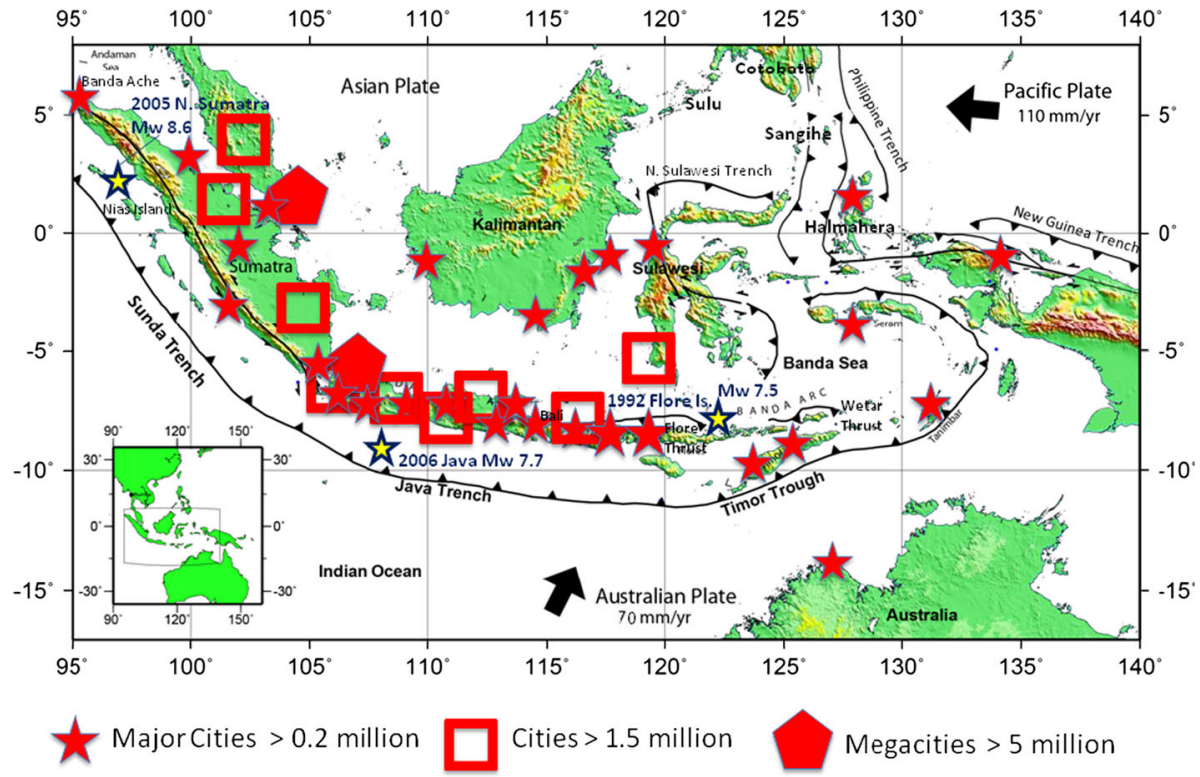

Fig. 1 Map of major cities and proximity to major plate boundary segments in the Indonesia region. The Indo-Australian Plate moves NNW at a rate of around $70 \mathrm{~mm} / \mathrm{year}$. The Pacific Plate moves WNW and sideswipes the northern part of the Banda Arc at a rate of $110 \mathrm{~mm} / \mathrm{year}$. Blue stars-epicentral locations and magnitudes of earthquakes mentioned in the paper 
nearly the same area estimated by Newcomb and McCann (1987) from accounts in the Wichmann catalog of an earthquake and tsunami in 1861 .

The $\mathrm{M}_{\mathrm{w}}$ 9.2 Banda Ache mega-thrust earthquake, and the spatial and temporal clustering of events that followed, has stimulated new interest in the earthquake history of the western Sunda Arc. All eyes are presently on the segment of the Sumatran subduction zone to the south of Nias, which last ruptured in 1833. From reports of this event and the tsunami that followed that are recorded in the Wichmann catalog Newcomb and McCann (1987) estimate, it could have been up to $M_{w} 9.0$.

The Sunda arc-trench system continues to the east of Sumatra adjacent to the densely populated islands of Java and Bali, then becomes the Banda Arc in the Timor region (Fig. 1). Although no earthquakes larger than $M_{w} 8.0$ are documented in the Java-Bali region, there are several earthquakes in the Banda Arc region documented before 1900 by Wichmann with similar characteristics to those in Sumatra. However, the source parameters of the large events are unknown. No large earthquakes in the Banda Arc and eastern Indonesia region are included in the recent summary of mega-thrust earthquake events worldwide by Heuret et al. (2012), which is based only on the last 100 years of instrumental records. When these largely unknown events reoccur in eastern Indonesia, it will affect an order of magnitude more people and urban centers than before (Fig. 1), which raises the stakes on determining the most likely large earthquake and tsunami sources in the region. This paper investigates the most likely source of one of the largest tsunami events documented in eastern Indonesian region, which occurred in 1629.

\section{Tectonic setting}

The Banda Arc region occupies a convergent triple junction of three of Earth's largest plates. Relative to the Sundaland block, a tectonic domain that is extruding eastward away from Eurasian Plate (Rangin et al. 1999), the Indo-Australian Plate converges NNE at a rate of around $70 \mathrm{~mm} / \mathrm{a}$ (Nugroho et al. 2009). The Indo-Australian Plate subducts beneath the Banda Arc from three sides along the Timor, Tanimbar and Seram Troughs. These troughs are underthrust mostly by Australian continental margin lithosphere that is attached to old Indian Ocean lithosphere at deeper levels of the subduction zone (Hamilton 1979). The resulting arc-continent collision bends $180^{\circ}$ around the western edge of NW Australia (Fig. 2). Another major tectonic player in the region is the Pacific Plate. It moves WNW at a rate of around $110 \mathrm{~mm} / \mathrm{a}$ relative to the Sundaland Plate (Rangin et al. 1999) and sideswipes the northern part of the Banda Arc along an array of plate boundary segments linked by the left-lateral Sorong fault (Figs. 1, 2).

The NW part of the Australian continental margin first began to subduct beneath the Banda Arc at around $8 \mathrm{Ma}$ in the Timor and Seram regions (Berry and McDougall 1986; Linthout et al. 1996; Harris 2011). The arc-continent collision has now propagated around the embayment south of the Bird's Head and involves the entire Banda Arc region (Hall 2002). Underthrusting of the Australian continental margin increases coupling along the subduction interface as indicated by partitioning of strain away from the deformation front into the forearc (Reed et al. 1986; Harris et al. 2009) and back arc regions (Silver et al. 1983). In the backarc, the volcanic arc is thrust over the southern edge of the Banda Sea Basin (Fig. 2) along the Flores and Wetar Thrusts (Breen et al. 1989). These south-dipping backarc thrust systems (Figs. 1,2) currently take up a significant amount of the convergence between the Australia and Asia plates (Mccaffrey and Nabelek 1984; Genrich et al. 1996). The amount of movement along these thrust systems decreases to the west where 


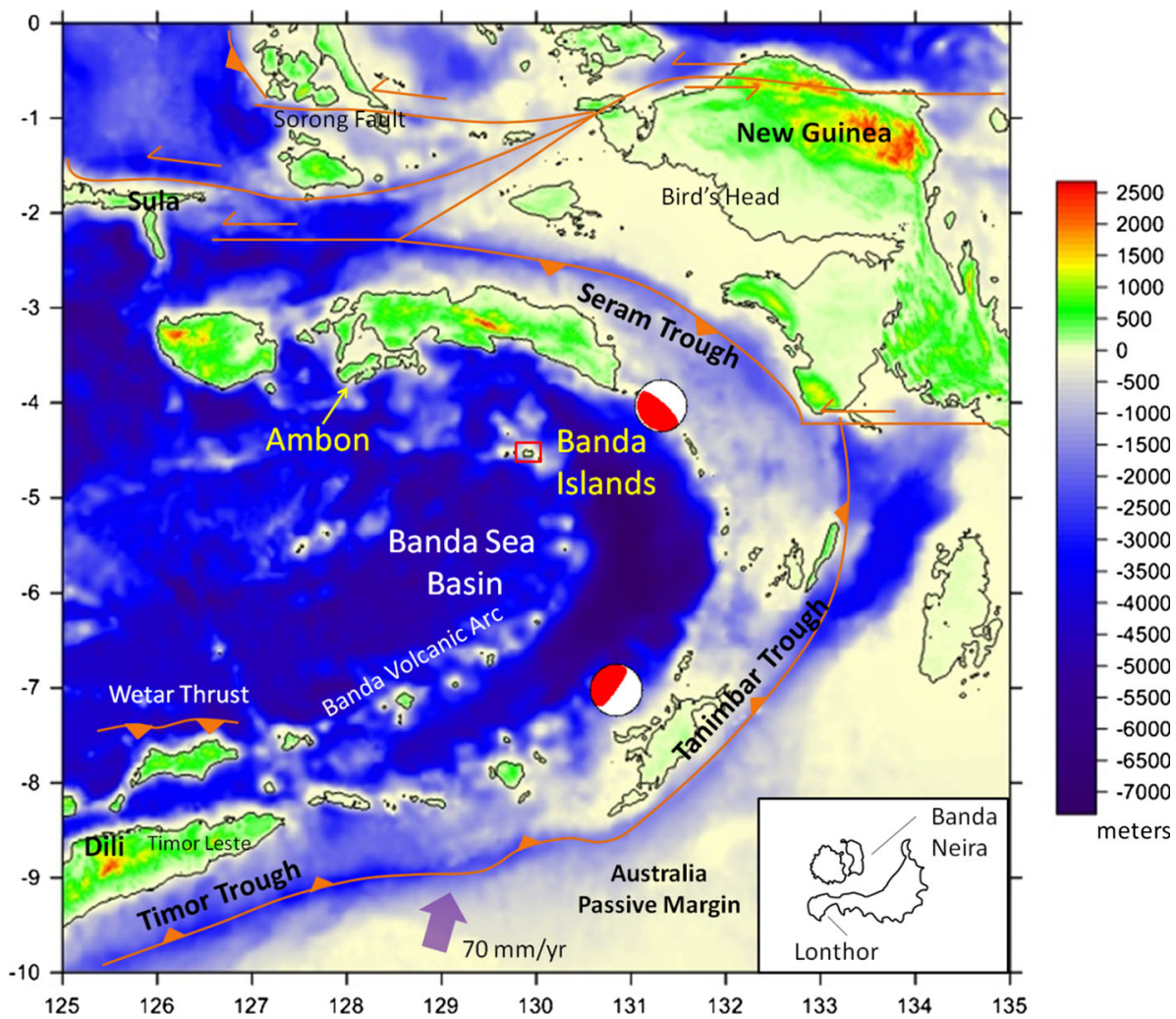

Fig. 2 Relief and bathymetry model of the Banda Sea and surrounding islands of the region. Active faults are shown in orange. The bathymetry is based on ETOPO-1 data with a grid size of 1 min. At this resolution, the Banda Islands of Banda Neira and Lonthor (inset) are identified, as is the shallow embayment protecting the city of Ambon. Two fault plane solutions we used for the modeling are marked on this map. See Sects. 4.1 and 4.2

the oblique collision is less developed (Silver et al. 1983). Even in the most advanced part of the collision in the Timor region, there is still up to $21 \mathrm{~mm} / \mathrm{a}$ of convergence measured across the Timor Trough (Nugroho et al. 2009), which means that a significant amount of elastic strain energy is accumulating along this plate boundary (Harris 2011).

The low rate of seismicity along the Timor, Tanimbar and Seram Troughs is commonly cited as evidence that they are no longer active (Mccaffrey and Nabelek 1984). However, seismic reflection profiles across the deformation front at the Seram, Tanimbar and Timor Troughs show thrust faults breaking all of the way to the surface (Schluter and Fritsch 1985; Karig et al. 1987; Pairault et al. 2003). We interpret the low seismic slip rates of the Banda collision zone as evidence of a locked plate boundary interface, which potentially could produce mega-thrust earthquakes. There are several small thrust-mechanism earthquakes along the low-angle plate interface of both the Timor and Seram Troughs. Although active thrusting is observed in earthquakes along the plate boundary in the Tanimbar Trough region, there are many extensional and strike-slip events as well (Mccaffrey and Nabelek 1984).

The backarc thrust systems may also produce large earthquakes. The mapped length of the Wetar Thrust is around $350 \mathrm{~km}$, which may be too short for a mega-thrust earthquake 
event. However, the Flores Thrust is at least $500 \mathrm{~km}$ in length, which, if the whole thrust system ruptured, may produce a mega-thrust earthquake.

The working definition here for a mega-thrust event is an interplate earthquake that occurs along a subduction interface, that is, $\mathrm{M}_{\mathrm{w}} \geq 8.5$ and is associated with uncommonly large rupture lengths $(>400 \mathrm{~km})$. The fault plane commonly has a shallow dip $\left(<10^{\circ}\right)$ and the earthquake, a shallow hypocenter $(<30 \mathrm{~km})$, which at a subduction zone can produce large tsunami.

Most mega-thrust earthquakes of the magnitude needed to produce the tsunami observed in the Banda Islands have rupture lengths of $>500 \mathrm{~km}$, such as $2010 \mathrm{M}_{\mathrm{w}} 8.8$ Maule "Chile" earthquake (Wang et al. 2012) and $2011 \mathrm{M}_{\mathrm{w}} 9.0$ Tohoku earthquake (Suzuki et al.2011). However, the most significant problem with either of the backarc thrust systems sourcing the 1629 tsunami is their distance $(>450 \mathrm{~km})$ from the Banda Islands where the tsunami arrived only 30 min after intense shaking (see Sect. 2.1 below).

It is also possible that unknown active faults exist close enough to the Banda Islands to generate a tsunami that arrives within $30 \mathrm{~min}$. For example, active strike-slip faults are inferred to the west of Banda Neira (Mccaffrey and Nabelek 1984) that, with a significant component of oblique slip, may produce a large tsunami if the rupture zone parameters are large enough. It is also possible that an earthquake-induced landslide generated the tsunami (Brune et al. 2010). Nevertheless, the extent to which the earthquake was felt, and the prolonged seismicity following the event, indicates that the earthquake was larger than any event occurring over the past 100 years of instrumental records.

\subsection{Testing for mega-thrust earthquakes}

Records of geophysical events throughout the Indonesian region date back to 1600 and are mainly compiled in "The Earthquakes of the Indian Archipelago" by Authur Wichmann (1918). This volume documents several large earthquakes and tsunami throughout the Banda Arc region that are characteristic of mega-thrust earthquake events.

It is possible that one of these events happened on August 1, 1629, in the eastern Banda Sea region:

A half hour after the termination of a violent seismic shock there formed in the sound ... a high mountain of water. The tidal wave rolled westward straight against fort Nassau on Banda Neira, as well as the village on the beach ... where it achieved a height of 9 fathoms $[15.3 \mathrm{~m}]$ above the springtide stand. The mole built of stone before the fort was beaten away and the water penetrated into the fort with such force, that a 3,500 pound heavy mass of iron was displaced by 36 feet $[11.3 \mathrm{~m}]$.

The records indicate that the tsunami arrived at the Banda Islands 30 min after the earthquake occurred. Based on the tsunami propagation equation:

$$
V=\sqrt{g D}=d / t
$$

where $V$ is velocity of the tsunami wave, $g$ is gravity, $D$ is the depth of the bathymetry, $d$ is the distance between rupture and the Banda Islands, $t$ is the tsunami arrival time, and the reasonable distance between the source of the tsunami and the Banda Islands is about 200-300 km.

In the Wichmann records, the earthquake was also felt in Ambon, which is $210 \mathrm{~km}$ to the $\mathrm{NW}$, but there is no record of a tsunami there. An unusually high rate of seismicity in the region followed the 1629 event and increasingly diminished after 9 years. Fifteen years after the 1629 earthquake, there were several other large earthquakes in and around Ambon, some 
of which caused tsunami. We interpret this temporal and spatial clustering of seismicity as stress contagion from the 1629 earthquake, which caused a series of aftershocks. The record of the possible aftershocks and the distance over which the earthquake was felt argues for a large, plate boundary earthquake as the most likely source of the tsunami. The extent over which the earthquake was felt may have been much larger than noted due to the lack of European outposts keeping records in the region during the seventeenth century.

The only plate boundary source region of a possible mega-thrust earthquake, that is, within 200-300 km from Banda Neira is the easternmost Banda arc-continent collision zone between Seram and Tanimbar (Fig. 2). This section of the collision zone is segmented around the Aru Trough region (Schluter and Fritsch 1985). We use this segment boundary to constrain the southern limit of Seram Trough rupture and the northern limit of Tanimbar Trough rupture (Fig. 2). Other plate boundary segments in the region, such as the Timor Trough, the Wetar or Flores backarc thrust, or the Sulawesi, Sangihe, Halmahera, Cotabato, New Guinea and Philippines Trenches, are too far away to generate a 15-m tsunami that arrives 30 min after violent shaking in the Banda Islands (Fig. 1). Seismological evidence is lacking for how the Seram, Tanimbar or Timor Troughs are segmented.

\section{Method}

The numerical solutions used for the model simulations are those of Satake (2002); Ma and Lee (1997) and Ma et al. (1991). The bathymetry for the model is based on ETOPO-1 data (Amante and Eakins 2009) with a grid size of 1 min (about $1.6 \mathrm{~km}$ ) (Fig. 2). At this resolution, the Banda Islands of Banda Neira and Lonthor are identified, as is the shallow embayment protecting the city of Ambon (Fig. 2).

\subsection{Vertical seafloor deformation}

Vertical seafloor deformation of the simulated earthquakes is modeled using the method by Okada (1985), which computes ground deformation caused by faulting in a homogeneous half-space. Since the fault parameters of the 1629 earthquake are unknown, we use those from focal mechanisms of instrumented, but smaller events along what is likely the collisional interface (Global CMT database, http://www.globalcmt.org/CMTsearch.html). Fault width and length are calculated from empirical equations (Table 1) derived from earthquake observations (Wells and Coppersmith 1994; Ma and Lee 1997).

\subsection{Tsunami propagation simulation}

From the vertical surface deformation and bathymetry models, tsunami propagation is computed using a finite difference method. Here, we use the linear relationship between tsunami amplitude and fault slip (Ma and Lee 1997; Satake 1995). We assume that the water surface is uplifted instantaneously exactly in the same way as the bottom

Table 1 Empirical equation used for all numerical simulations, based on Wells and Coppersmith (1994)

$$
\begin{aligned}
& \text { Empirical equation of thrust fault } \\
& \begin{array}{l}
\mathrm{M}_{\mathrm{w}}=(5.00 \pm 0.22)+(1.22 \pm 0.16) \log (L) \\
\mathrm{M}_{\mathrm{w}}=(4.37 \pm 0.16)+(1.95 \pm 0.15) \log (W) \\
\mathrm{M}_{\mathrm{w}}=(6.52 \pm 0.11)+(0.44 \pm 0.26) \log (D)
\end{array}
\end{aligned}
$$


deformation. Computations were made for a total duration of $8 \mathrm{~h}$ at time increments of $5 \mathrm{~s}$. A linear model is used to compute wave amplitudes along the coastal regions of Banda Island and Ambon that are based on the ratio of computed tsunami run-up heights to observed heights, which is known as amplification factor.

\subsection{Tsunami run-up amplification factor}

We calibrated the amplification factor by modeling the nearby 1992 tsunami of Flores Island (Hidayat et al. 1995) and 2006 slow earthquake tsunami in Java (Koshimura 2006) (Fig. 1). These two very different tsunamigenic earthquakes in the region provide the widest possible range of direct measurements of wave and run-up heights.

\subsubsection{December 12, 1992, Flore Island, Indonesia, earthquake}

On December 12, 1992, an $\mathrm{M}_{\mathrm{w}} 7.7$ earthquake occurred near the north shore of Flores Island along the Flores backarc thrust system (Fig. 1). The earthquake and the ensuing tsunami killed around 4,000 people. Most tsunami run-up heights along the northern shore of Flores Island were $2-5 \mathrm{~m}$. Here, we reproduce the same fault model used by Hidayat et al. (1995) who derive fault parameters from inverting teleseismic, broadband P and SH waves, as well as PP waves for the seismic moment rate tensor. The model uses a two-fault source to generate vertical seafloor deformation. The fault parameters and vertical deformation can be found in Hidayat et al. (1995). The only difference between earlier models and ours is the higher bathymetric resolution we use. Hidayat et al. (1995) use the ETOPO5 data with grid size of 5 min versus the much higher-resolution ETOPO-1 model we use with a 1-min grid size. Previous studies (Satake 1995) show that observed and theoretical tsunami heights are closer with a smaller grid size.

Tsunami run-up heights were measured along the northeast coast of Flores Island by multiple international survey teams (Table 2). However, only one tide gauge, Palpo, which is $650 \mathrm{~km}$ north of Flore Island, recorded open ocean wave heights (Fig. 3). Comparing wave heights computed by our model waveforms with those observed by the tide gauge yields an amplification factor of 1.5 for this tsunami (Table 2). These results improved upon those of Hidayat et al. (1995) by better fitting the observed run-up heights. Locally, tsunami run-up heights were amplified by a submarine landslide caused by the earthquake.

\subsubsection{July 17, 2006, south of Java Island, Indonesia, earthquake}

A large earthquake $\left(\mathrm{M}_{\mathrm{w}}\right.$ 7.7) occurred along the subduction interface south of Java Island on July 17, 2006, which generated a tsunami causing around 800 casualties. Maximum runup heights along the southern shore of Java are from 1 to $4.6 \mathrm{~m}$ (Hariri and Bilek 2011). Here, we reproduce the fault model in Koshimura (2006) based on Harvard CMT fault parameters, but with the higher-resolution bathymetry (ETOPO-1 versus ETOPO-2). Runup heights (Table 3) are taken from those measured along the southern Java coast by Kongko et al. (2006). Comparison of our modeled tsunami heights with the observed data indicates an amplification factor of around 4 in this case.

However, the Java earthquake is a unique case of slow rupture that was hardly felt by those on shore (Koshimura 2006). Kato et al. (2007) made GPS observations and tsunami height measurements during the event period, but no co-seismic displacement was detected. In their paper, the observed tsunami heights are systematically higher than those predicted from numerical simulations based on seismic wave analysis, which indicates that 
Table 21992 Flores earthquake observed and calculated tsunami run-up heights (in m) based on Hidayat et al. (1995)

\begin{tabular}{|c|c|c|c|c|c|c|}
\hline Station & Name & Lat & Lon & Observed (m) & $\begin{array}{l}\text { Two-fault } \\
\text { model by } \\
\text { Hidayat } \\
\text { et al. (1995) }\end{array}$ & $\begin{array}{l}\text { Model predicted } \\
(\mathrm{m}) \text { with } \\
\text { amplification } \\
\text { factor } 1.5\end{array}$ \\
\hline 1 & Mage, Palu Is. & -8.3 & 121.75 & 2.8 & 1.79 & 1.24 \\
\hline 2 & Mausanbi & -8.5 & 121.78 & 3.4 & 3.15 & 3.27 \\
\hline 3 & Awora & -8.48 & 121.85 & 2.9 & 2.90 & 4.71 \\
\hline 4 & Deteh & -8.53 & 122.03 & 2.3 & 5.88 & 3.62 \\
\hline 5 & Patisomba & -8.55 & 122.15 & 4 & 4.11 & 4.97 \\
\hline 6 & Nangahureh & -8.55 & 122.17 & 1.9 & 3.44 & 3.23 \\
\hline 7 & Wailiti & -8.57 & 122.18 & 2.1 & 3.43 & 3.42 \\
\hline 8 & Wuring & -8.6 & 122.2 & 3.2 & 3.67 & 3.29 \\
\hline 9 & Maumere & -8.62 & 122.23 & 3 & 2.95 & 2.82 \\
\hline 10 & Waioti & -8.63 & 122.27 & 2.5 & 3.46 & 3.47 \\
\hline 11 & Geliting & -8.63 & 122.28 & 3.3 & 3.63 & 3.84 \\
\hline 12 & Egon & -8.6 & 122.42 & 1.8 & 4.05 & 1.95 \\
\hline 13 & Wodung & -8.58 & 122.48 & 2.3 & 4.69 & 4.11 \\
\hline 14 & Nangahale & -8.55 & 122.5 & 1.5 & 3.58 & 3.83 \\
\hline 15 & Talobura & -8.52 & 122.52 & 2.4 & 5.52 & 2.94 \\
\hline 16 & Ngolo, Pomana Is. & -8.35 & 122.32 & 3.2 & 1.97 & 3.68 \\
\hline 17 & Buton, Pomana Is. & -8.33 & 122.33 & 1.5 & 2.23 & 3.41 \\
\hline 18 & Taot, Desar Is. & -8.87 & 122.35 & 2.8 & 1.33 & 0.01 \\
\hline 19 & Kusung, Besar Is. & -8.87 & 122.42 & 4.1 & 2.62 & 0.01 \\
\hline 20 & Permahan Is. & -8.45 & 122.45 & 3.4 & 3.21 & 3.02 \\
\hline 21 & Babi Is. N & -8.4 & 122.52 & 4 & 2.12 & 3.08 \\
\hline 22 & Babi Is. W & -8.42 & 122.5 & 7.1 & 2.40 & 2.72 \\
\hline 23 & Babi Is. $\mathrm{S}$ & -8.43 & 122.52 & 4 & 3.76 & 3.39 \\
\hline 24 & Babi Is. E & -8.42 & 122.53 & 5.6 & 2.69 & 2.40 \\
\hline 25 & Nebe & -8.45 & 122.53 & 4.6 & 5.11 & 3.39 \\
\hline 26 & Wailamung & -8.42 & 122.58 & 5.5 & 6.92 & 3.11 \\
\hline 27 & Larentuka & -8.37 & 122.98 & 1.8 & 1.97 & 1.17 \\
\hline 28 & Pantai Lato & -8.37 & 122.77 & 3.8 & 3.59 & 4.62 \\
\hline
\end{tabular}

The tsunami run-up heights in last column of this table are predicted by our model

fault offset may be larger than estimates using seismic analysis and the rupture was very slow. Thus, in our model, we set the maximum limit of amplification as a factor of 4 .

In summary, the tsunami run-up amplification factors of 1.5 and 4 that we determined from modeling two different earthquakes in the eastern Indonesia region provide upper and lower limits on the moment magnitudes for earthquakes we model on the Tanimbar and Seram Troughs.

\section{Results}

The most likely active faults that could produce the violent shaking (felt over $300 \mathrm{~km}$ radius), a tsunami with run-up heights at least up to $15 \mathrm{~m}, 9$ years of possible aftershocks and perhaps stress contagion to nearby faults are the Tanimbar (South Source) and Seram 


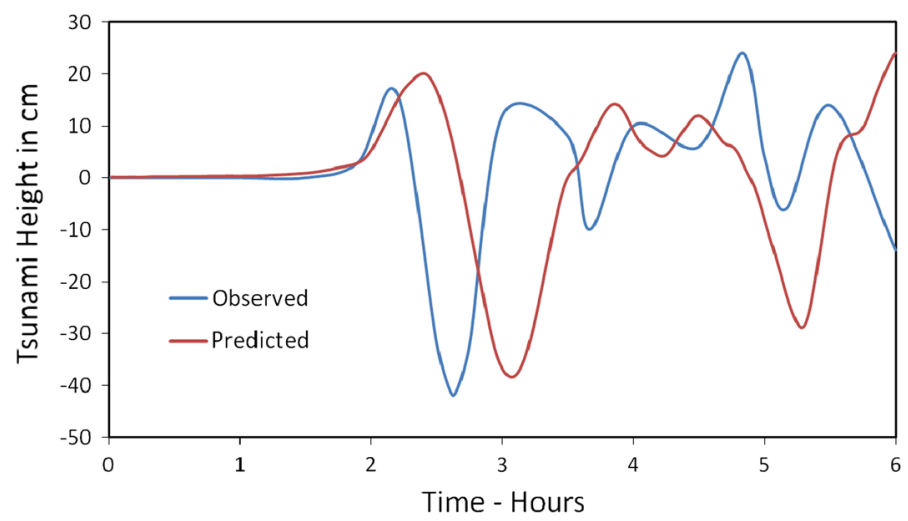

Fig. 3 Comparison of observed tsunami waveform (blue) and computed waveform (red) in the tide gauge, Palpo, which is $650 \mathrm{~km}$ north of the December 12, 1992, Flore Island, Indonesia, earthquake event

Table 32006 Java earthquake observed and calculated tsunami run-up height (in m)

\begin{tabular}{llllll}
\hline Station & Name & Lat & Lon & Observed (m) & $\begin{array}{l}\text { Model predicted (m) } \\
\text { with amplification } \\
\text { factor } 4\end{array}$ \\
\hline 1 & Keburuhan & -7.88 & 109.90 & 2.5 & 1.3 \\
2 & Suwuk & -7.75 & 109.50 & 1.1 & 1.6 \\
3 & Ayah & -7.70 & 109.38 & 1.5 & 2.1 \\
4 & Widarapayung & -7.65 & 109.25 & 4.6 & 1.9 \\
5 & Bunton & -7.62 & 109.13 & 1.5 & 1.7 \\
6 & Cikembulan 1 & -7.72 & 108.55 & 3.1 & 3.2 \\
7 & Cikembulan 2 & -7.65 & 108.60 & 3.6 & 2.8 \\
8 & Pengandaran 1 & -7.62 & 108.65 & 2.9 & 2.9 \\
9 & Pengandaran 2 & -7.62 & 108.70 & 2.7 & 1.5 \\
\hline
\end{tabular}

(East source) sections of the Banda arc-continent collision zone. The Seram Trough is from 220 to $300 \mathrm{~km}$ to the east of Banda Neira, while the Tanimbar Trough is at least 400-440 km away, respectively (Fig. 2). We primarily use the tsunami arrival times and wave heights predicted by earthquakes of various magnitudes to constrain which of the source regions are most likely. The direction of the wave and the fact that it was not observed in Ambon help us further constrain the most likely source region. We follow our modeling procedure to identify which fault parameters and range of earthquake magnitudes for these two potential sources best coincide with the historic records.

\subsection{Tanimbar Trough (south source)}

For fault parameters of the Tanimbar Trough, we extrapolate focal mechanism data associated with the 2004/10/22 earthquake event recorded in the Global CMT database (Tables 1,4), which is consistent with seismic reflection profiles of the plate boundary interface (Schluter and Fritsch 1985). The epicenter of the earthquake is at $7.27^{\circ} \mathrm{S}$ and $130.5^{\circ} \mathrm{E}$. The hypocenter is on the plate boundary interface shown by Welc and Lay (1987). A simple two-fault-segment model is used to match the curved shape of Tanimbar Trough. 
Table 4 Fault parameters used for numerical simulations

\begin{tabular}{|c|c|c|c|c|c|c|c|}
\hline $\begin{array}{l}\text { Length } \\
(\mathrm{km})\end{array}$ & $\begin{array}{l}\text { Width } \\
(\mathrm{km})\end{array}$ & $\begin{array}{l}\text { Strike } 1 \\
\left({ }^{\circ}\right)\end{array}$ & $\begin{array}{l}\text { Strike } 2 \\
\left({ }^{\circ}\right)\end{array}$ & $\begin{array}{l}\text { Dip } \\
\left({ }^{\circ}\right)\end{array}$ & $\begin{array}{l}\text { Depth } \\
(\mathrm{km})\end{array}$ & $\begin{array}{l}\text { Max slip } \\
\text { (m) }\end{array}$ & $\begin{array}{l}\text { Min slip } \\
(\mathrm{m})\end{array}$ \\
\hline
\end{tabular}

South source-Tanimbar Trough (maximum $M_{w}$ : 9.8; minimum $M_{w}: 9.2$ )

$\begin{array}{llllll}450 & 112 & 220 & 260 & 10 & 20\end{array}$

40.9

14.96

East source-Seram Trough (maximum $M_{w}: 8.8$; minimum $M_{w}: 8.2$ )

\begin{tabular}{llllllll}
500 & 97 & 118 & 160 & 10 & 15 & 11.6 & 6.2 \\
\hline
\end{tabular}

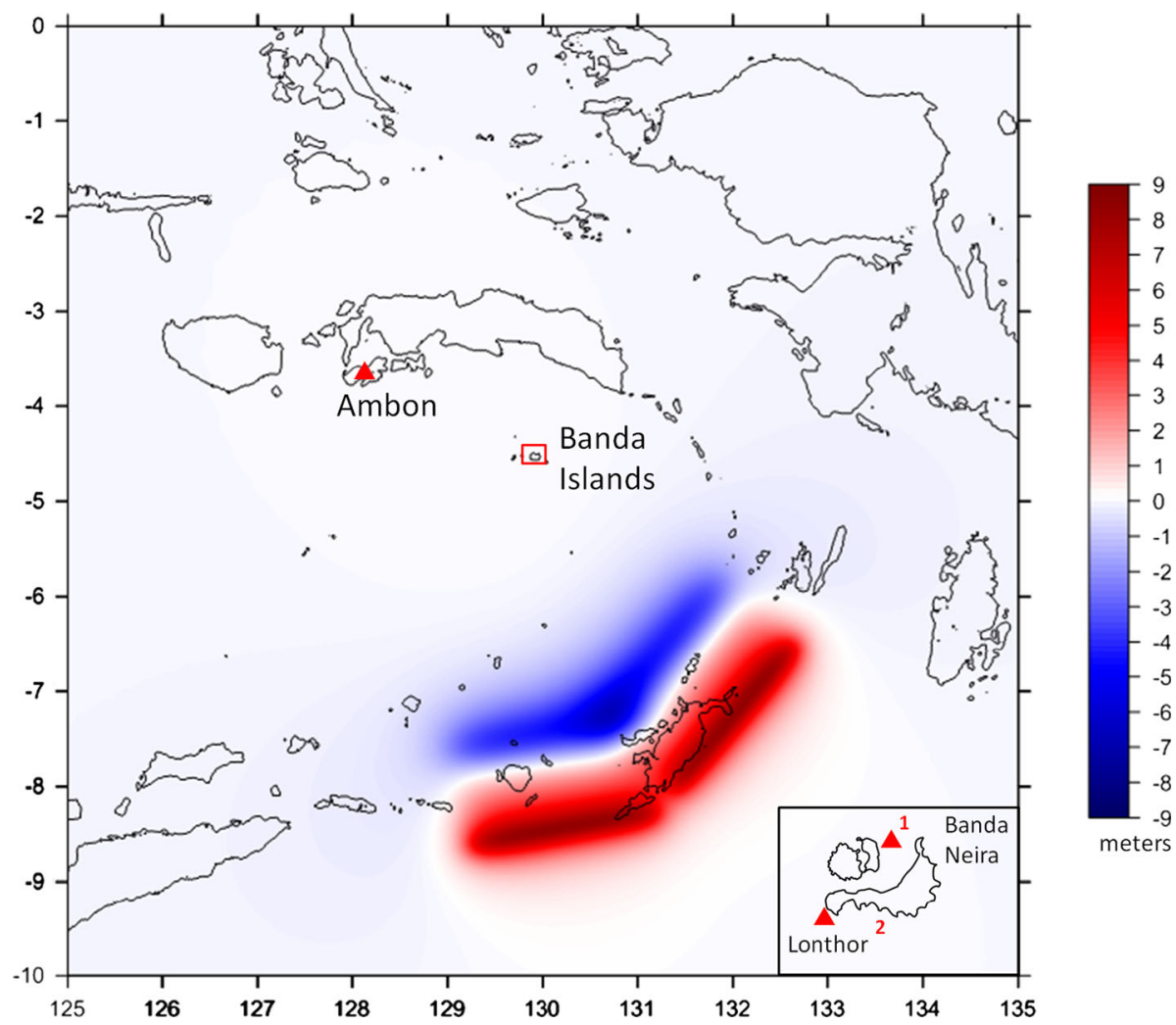

Fig. 4 The vertical component of surface deformation estimated from the two-fault-segment model of the Tanimbar forearc. The fault plane parameters can be found in Table 4. Uplift is shown as red and subsidence in blue. The city of Ambon and the simulated gauge station are indicated as a red triangle. Triangles 1 and 2 represent the simulated gauge stations for Banda Neira and Lonthor islands

A vertical crustal deformation of $6 \mathrm{~m}$ is required to produce a tsunami as large as that observed in the Banda Islands with the maximum amplification factor of 4 (Fig. 4). According to the scaling relations, this deformation would require an earthquake of $\mathrm{M}_{\mathrm{w}} 9.2$ as a minimum magnitude. However, the maximum earthquake magnitude with amplification factor of only 1.5 is 9.8 for a tsunami run-up of $15 \mathrm{~m}$ in Banda Islands. The finiteelement-based tsunami simulation predicts a tsunami arrival time at the Banda Islands of about $58 \mathrm{~min}$ after the initiation of the earthquake (Fig. 5). Although the numerical model predicts tsunami heights of $15 \mathrm{~m}$, which are close to those observed at the Banda Islands, it also predicts first arrival tsunami heights $>5 \mathrm{~m}$ for Ambon, which was not observed. 

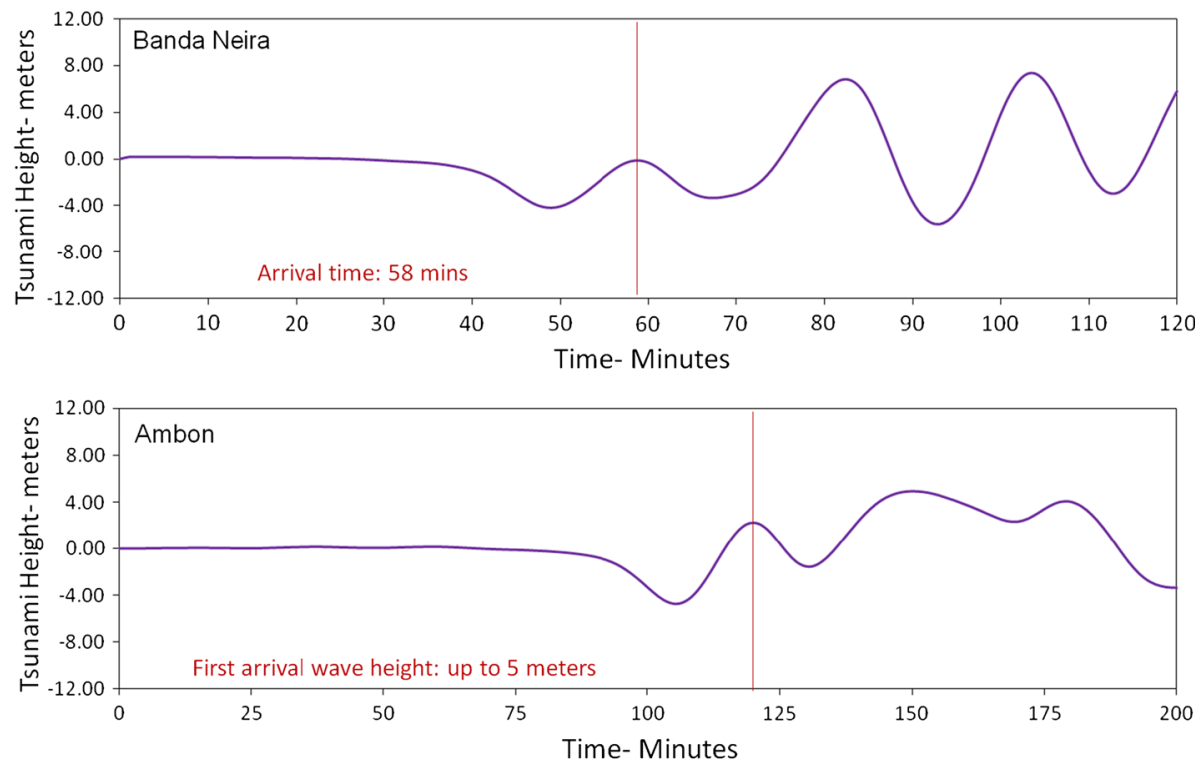

Fig. 5 Computed tide gauge records and tsunami waveform for Banda Neira and Ambon city stations from the Tanimbar Trough model earthquake. The tsunami arrival time at the Banda Islands is 58 min after the initiation of the earthquake, which is nearly twice as long as observed. The model also predicts tsunami runup heights $>5 \mathrm{~m}$ at Ambon city using the minimum amplification factor of 1.5, which was not observed

\subsection{Seram Trough (east source)}

For fault parameters of the Seram Trough, we use focal mechanism data from the 1993/12/ 04 earthquake (Table 4), which is along the boundary interface. A simple two-fault-segment model is employed to match the curved shape of the Seram Trough fault zone with $\mathrm{L}=500 \mathrm{~km}, \mathrm{~W}=97 \mathrm{~km}$ and $\mathrm{D}=116 \mathrm{~cm}$ (Fig. 6 and Table 4). The epicenter of the model event is $4^{\circ} \mathrm{S}$ and $131.14^{\circ} \mathrm{E}$. The maximum earthquake magnitude of $\mathrm{M}_{\mathrm{w}} 8.8$ is required to generate a $15-\mathrm{m}$ tsunami in the Banda Islands if the minimum amplification factor of 1.5 is applied. The minimum earthquake magnitude of $M_{w} 8.2$ is estimated with a tsunami amplification factor of 4 . The Seram trough source simulation yields a slip $=11.6 \mathrm{~m}$ in order to produce a $15.3-\mathrm{m}$ tsunami. This result is consistent with "Plafker's rule of thumb" (Okal and Synolakis 2004) that a seismic dislocation does not produce run-up heights much in excess of its own amplitude of slip. The minimum estimate of tsunami arrival at the Banda Islands is 30 min after the initiation of the earthquake (Figs. 7, 8). Another important result is that the best-fit model tsunami produces wave heights in Ambon of less than one meter, which is consistent with the observations of feeling the earthquake, but no tsunami noted.

\subsection{Sensitivity analysis}

We conducted a sensitivity analysis of our numerical methods in order to better understand how variations in hypocentral depth and fault dip from Seram Trough earthquake influence modeled tsunami heights (Fig. 9). The other fault parameters (Table 4) remained fixed for 


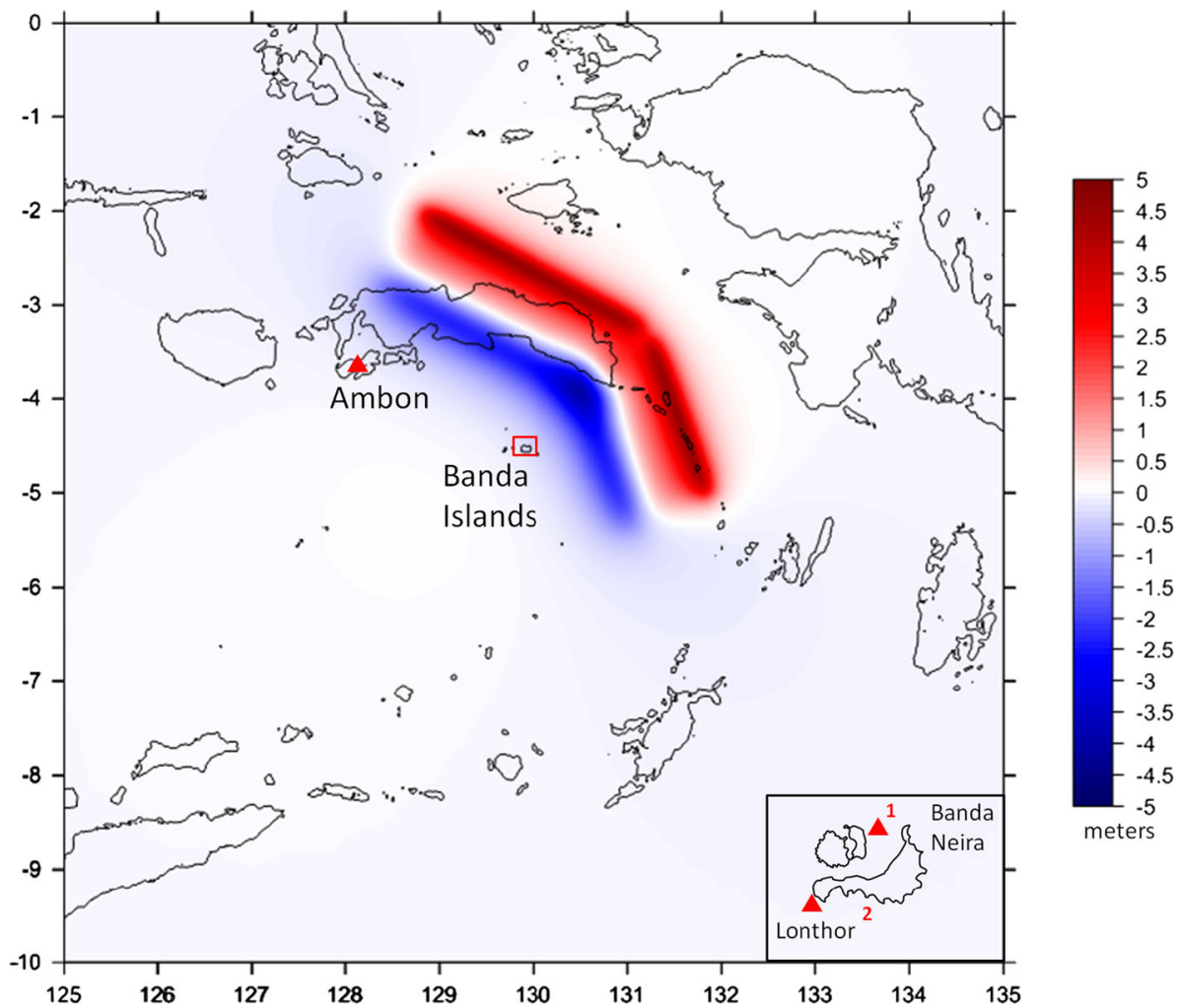

Fig. 6 The vertical component of surface deformation for the Seram forearc, estimated from the two-faultsegment model. The fault plane parameters are given in Table 4. The color scheme and stations are the same as Fig. 4

each model. For analyzing the influence of fault dip, we vary dip values by increments of $5^{\circ}$ between dips of $10^{\circ}$ and $45^{\circ}$. For analyzing the influence of hypocentral depth, we vary depths by increments of $5 \mathrm{~km}$ from depths of 10 to $30 \mathrm{~km}$.

Changes in the dip angle of the fault influence tsunami height most, by a factor of $>2$ between $10^{\circ}$ and $45^{\circ}$ (Fig. 9a). This is not surprising due to the increase in vertical displacement caused by increasing dip angles. Variations in hypocentral depth have very little influence $(<10 \%)$ on tsunami height.

\section{Discussion}

\subsection{Evaluation of the source of 1629 Banda mega-thrust earthquake and tsunami}

The poorest fit between model predictions and observation is with the Tanimbar Trough source. There are four important misfits: (1) waves approach Banda Neira from the south rather than from the east as observed in the record, (2) a much larger magnitude is required along the Tanimbar Trough $\left(\mathrm{M}_{\mathrm{w}}=9.8-9.2\right)$ to produce the observed run-up heights in Banda Neira, (3) the wave takes twice as long to arrive as observed and (4) run-up heights 

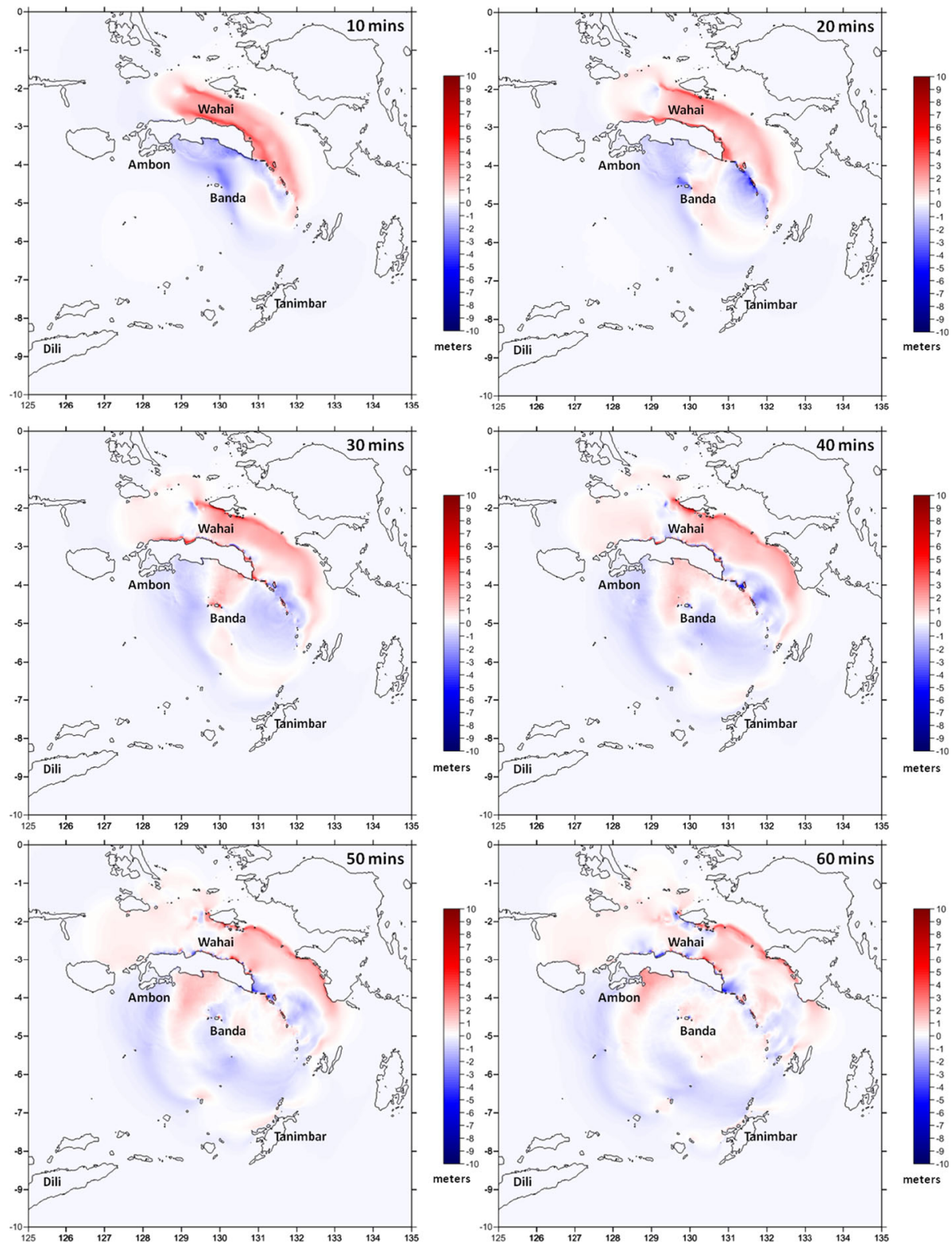

Fig. 7 Snapshots of the first $60 \mathrm{~min}$ of tsunami propagation for the two-fault-segment model of Seram Trough earthquake. Positive wave amplitude is shown in red, and negative wave amplitude is shown in blue. The large positive wave amplitude hits the Banda Islands after $20 \mathrm{~min}$ and remains large in shallow coastal areas

in Ambon are at least $5 \mathrm{~m}$, which would have destroyed much of Ambon. Therefore, we conclude that the most likely source of the 1629 mega-thrust earthquake is the Seram Trough. 

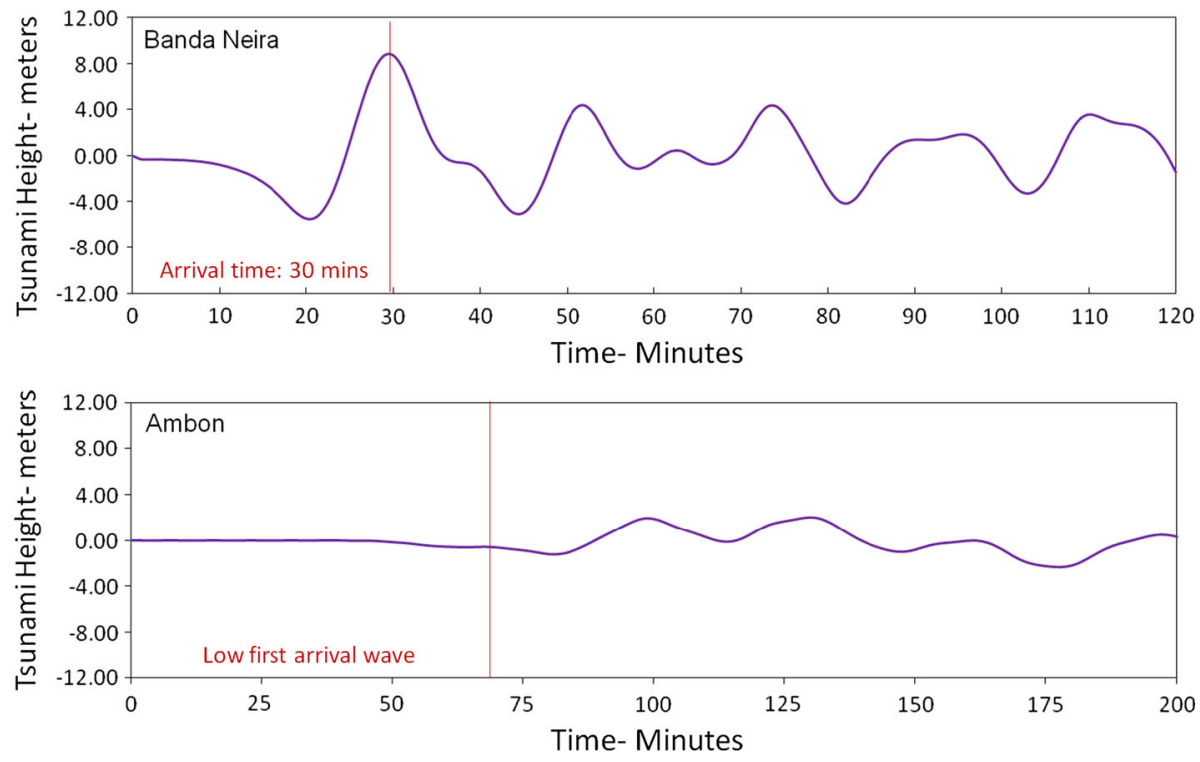

Fig. 8 Computed tide gauge records and tsunami waveform for Banda Neira and Ambon city stations from the Seram Trough model earthquake. The best-fit model tsunami produces wave heights in Ambon of $<1 \mathrm{~m}$, which is consistent with no mention of the tsunami there. The tsunami arrival time at the Banda Islands is $30 \mathrm{~min}$ after the initiation of the earthquake

We are also confident that the fault parameters we estimated for the Seram Trough are viable and not influencing the model adversely. High tsunami run-ups in Banda Neira may also result from local bathymetric effects that are below the resolution of available bathymetric data. However, this uncertainty does not change the better fit of a Seram Trough versus a Tanimbar Trough source, or the requirement for an earthquake along the Seram Trough larger than any observed since 1629.

\subsection{Implication to tsunami hazard for eastern Indonesia}

Only one earthquake $>\mathrm{M}_{\mathrm{w}} 8.0$ is recorded instrumentally from the eastern Indonesia region. It happened in 1938 in the middle of the Banda Sea north of Tanimbar. Little is known about the event (Okal and Reymond 2003), but the tsunami was small and caused no damage. In 1899, a $\mathrm{M}_{\mathrm{s}}=7.8$ earthquake struck the Seram region and generated a $10-\mathrm{m}$ tsunami, that was perhaps landslide-assisted, killing around 3,500 persons (Brune et al. 2010). With elastic strain energy accumulating across the Seram Trough at a rate of $50-80 \mathrm{~mm} / \mathrm{a}$ (Bock et al. 2003), it is likely that earthquake recurrence intervals are short ( $\sim 100$ years).

With little to no large earthquakes along the Seram Trough since 1899 and perhaps much earlier, we are concerned about the hazard potential of this very active tectonic region. During the past century, population and urbanization in the region have increased tenfold, particularly in coastal inundation zones (Fig. 1). The tsunami potential also threatens large cities outside the region. For example, our Seram Trough tsunami model predicts a 3-m wave in Dili, which is the capital of Timor Leste and a 5.3-meter wave in the north coast of Tanimbar (Fig. 10 and Table 5). 

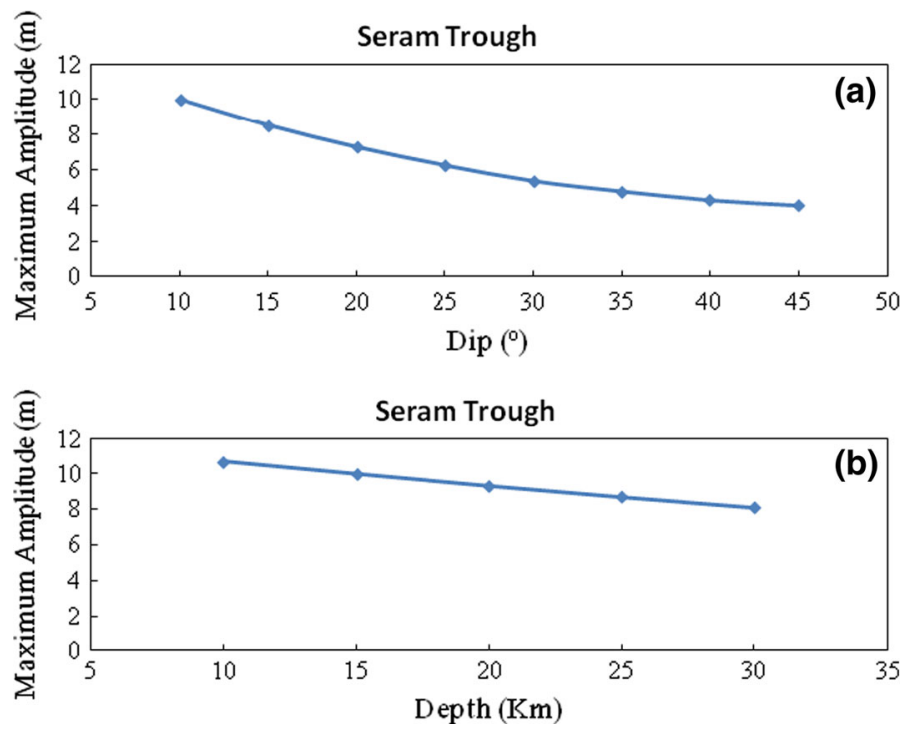

Fig. 9 Sensitivity of tsunami amplitude to fault parameters for Seram Trough. Amplitude as function of fault dip (a) and hypocentral depth (b)

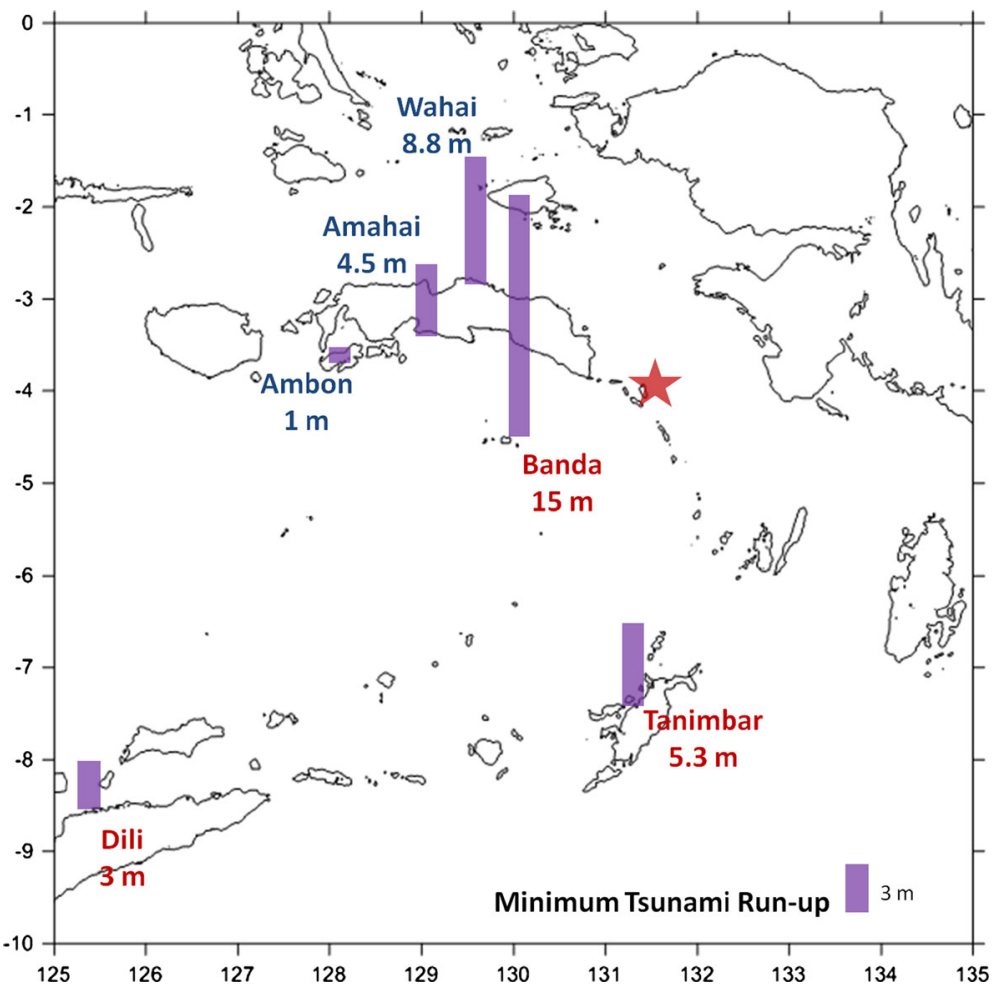

Fig. 10 Minimum tsunami run-up estimates for coastal cities from 1629 Seram Trough mega-thrust earthquake simulation. Star is the epicenter for the simulation 
Table 5 Predicted tsunami run-up using minimum amplification factor of 1.5 from $\mathrm{M}_{\mathrm{w}} 8.8$ earthquake and maximum amplification factor of 4 from $\mathrm{M}_{\mathrm{w}} 8.3$ earthquake along Seram Trough

\begin{tabular}{llllllll}
\hline Major city & Banda & Ambon & $\begin{array}{c}\text { Wahai } \\
\text { Seram }\end{array}$ & Amahai & Tanimbar & $\begin{array}{c}\text { Dili } \\
\text { Darwin } \\
\text { Australia }\end{array}$ \\
\hline Minimum tsunami height $(\mathrm{m})$ & 15.5 & 1 & 8.8 & 4.5 & 5.3 & 3 & 1 \\
\hline
\end{tabular}

\section{Conclusion}

This study reveals for the first time the potential of the Seram Trough for generating subduction interface mega-thrust earthquakes and associated large tsunami that carries the destructive force of the earthquake to many urbanized coastal areas of the eastern Indonesian region. The Banda Sea region has the highest number of historic tsunami in Indonesia (Latief et al. 2000). Yet, it also is one of the regions least aware of tsunami hazards. We urge local officials to not underestimate the disaster potential of the active Banda arc-continent collision and imminent threat of tsunami hazards.

Acknowledgments The project was funded in part by NSF grant EAR 0948386 and the BYU College of Physical and Mathematical Sciences. We would like to thank Kuo-Fong Ma, the faculty of Institute of Geophysics at National Central University, Taiwan, who shared their tsunami code with us. We also thank others involved in compiling data for the project, including Jon Major, Nate Baird, Tsz Man Fisher and Rachel Otte. Bill McCann and Steve Ward provided invaluable direction and encouragement. Seth Stein and anonymous reviewers provided valuable suggestions for improving the manuscript.

Open Access This article is distributed under the terms of the Creative Commons Attribution License which permits any use, distribution, and reproduction in any medium, provided the original author(s) and the source are credited.

\section{References}

Amante C, Eakins BW (2009) ETOPO1 1 Arc-minute global relief model: procedures, data sources and analysis. NOAA Technical Memorandum NESDIS NGDC-24, 19

Berry RF, McDougall I (1986) Interpretation of (super 40) Ar/(super 39) Ar and K/Ar dating evidence from the Aileu Formation, East Timor, Indonesia. Chem Geol Isot Geosci 59(1):43-58

Bock Y, Prawirodirdjo L, Genrich JF, Stevens CW, McCaffrey R, Subarya C, Puntodewo SSO, Calais E (2003) Crustal motion in Indonesia from Global Positioning System measurements. J Geophys Res 108:2367. doi:10.1029/2001JB000324

Breen NA, Silver EA, Roof S (1989) The Wetar back arc thrust belt Eastern Indonesia-the effect of accretion against an irregularly shaped arc. Tectonics 8(1):85-98

Brune S, Babeyko AY, Ladage S, Sobolev SV (2010) Landslide tsunami hazard in the Indonesian Sunda arc. Nat Hazards Earth Syst Sci 10(3):589-604

Genrich JF, Beck Y, McCaffrey R, Calais E, Stevens CW, Subarya C (1996) Accretion of the southern Banda arc to the Australian plate margin determined by Global Positioning System measurements. Tectonics 15(2):288-295

Hall R (2002) Cenozoic geological and plate tectonic evolution of SE Asia and the SW Pacific: computer based reconstructions, model and animations. J Asian Earth Sci 20:353-431

Hamilton WB (1979) Indonesia Departemen Pertambangan, United States. Agency for International Development and Geological Survey (US). Tectonics of the Indonesian region

Hariri ME, Bilek SL (2011) Stress changes and aftershock distribution of the 1994 and 2006 Java subduction zone earthquake sequences. J Geophys Res 116(B06306):14. doi:10.1029/2010JB008124

Harris RA (2011) The nature of the Banda arc-continent collision in the Timor region arc-continent collision. Springer, Heidelberg, pp 163-211

Harris RA, Donaldson K, Prasetyadi C (1997) Geophysical disaster mitigation in Indonesia using GIS. Buletin Teknologi Mineral 5:2-10 
Harris RA, Vorkink MW, Prasetyadi C, Roosmawati N, Zobell E, Apthorpe M (2009) Transition from subduction to arc-continent collision: geological and neotectonic evolution of Savu, Indonesia. Geosphere 5(3):152-171. doi:10.1130/GES00209.1

Heuret A, Conrad CP, Funiciello F, Lallemand F, Sandri F (2012) Relation between subduction Megathrust earthquakes, trench sediment thickness and upper plate strain. Geophys Res lett 39:L05304

Hidayat D, Barker JS, Satake K (1995) Modeling the seismic source and tsunami generation of the December 12, 1992 Flores Island, Indonesia, Earthquake. Pure Appl Geophys 144(3-4):537-554

Karig DE, Barber AJ, Charlton TR, Klemperer S, Hussong DM (1987) Nature and distribution of deformation across the Banda arc Australian collision zone at Timor. Geol Soc Am Bull 98(18):32

Kato T, Ito T, Abidin HZ, Agustan (2007) Preliminary report on crustal deformation surveys and tsunami measurements caused by the July 17, 2006 south off Java Island earthquake and tsunami, Indonesia. Earth Planets Space 59:1055-1059

Kongko W et al (2006) Rapid survey on java tsunami 17 July 2006. http://ioc3.unesco.org/itic/files/tsunamijava170706_e.pdf

Koshimura S (2006) http://www.tsunami.civil.tohoku.ac.jp/hokusai2/disaster/06_Java/July17_Java.html

Latief H, Puspito NT, Imamura F (2000) Tsunami catalog and zones in Indonesia. J Nat Disaster Sci 2(1):25-43

Linthout K, Helmers H, Wijbrans JR, Diederik J, Van Wees AM (1996) 40Ar/39Ar constraints on obduction of the Seram ultramafic complex: consequences for the evolution of the southern Banda Sea. In: Hall R, Blundell D (eds) Tectonic evolution of southeast Asia. Geol Soc Spec Publ (106):455-464

Ma K-F, Lee M-F (1997) Simulation of historical tsunamis in Taiwan region. J.Terr Atmos Ocean Sci (TAO) 8(1):13-30

Ma KF, Satake K, Kanamori H (1991) The origin of the tsunami excited by the 1989 Loma-Prieta earthquake-faulting or slumping. Geophys Res Lett 18(4):637-640

Mccaffrey R, Nabelek J (1984) The geometry of back arc thrusting along the eastern Sunda arc, Indonesiaconstraints from earthquake and gravity-data. J Geophys Res 89(Nb7):6171-6179

Newcomb KR, McCann WR (1987) Seismic history and seismotectonics of the Sunda arc. J Geophys Res 92(B1):421-439

Nugroho H, Harris R, Lestariya AW, Maruf B (2009) Plate boundary reorganization in the active Banda Arc-continent collision: insights from new GPS measurements. Tectonophysics 479(1-2):52-65

Okada Y (1985) Surface deformation due to shear and tensile faults in a half-space. Bull Seismol Soc Am 75(4):1135-1154

Okal EA, Reymond D (2003) The mechanism of great Banda sea earthquake of 1 February 1938: applying the method of preliminary determination of focal mechanism to a historical event. Earth Planet Sci Lett 216(1-2):1-15

Okal EA, Synolakis C (2004) Source discriminants for near-field tsunamis. Geophys J Int 158:899-912

Pairault AA, Hall R, Elders CF (2003) Structural styles and tectonic evolution of the Seram Trough, Indonesia. Mar Pet Geol 20:1141-1160

Rangin C, Le Pichon X, Mazzotti S, Pubellier M, Chamot-Rooke N, Aurelio M, Walpersdorf A, Quebral R (1999) Plate convergence measured by GPS across the Sundaland/Philippine sea plate deformed boundary: the Philippines and eastern Indonesia. Geophys J Int 139:296-316. doi:10.1046/j.1365246x.1999.00969.x

Reed DL, Silver EA, Prasetyo H, Meyer AW (1986) Deformation and sedimentation along a developing terrane suture: Sunda forearc, Indonesia. Geology 14:1000-1003. doi:10.1130/00917613

Satake K (1995) Linear and nonlinear computations of the 1992 Nicaragua earthquake tsunami. Pure Appl Geophys 144(3-4):455-470

Satake K, (2002) Tsunamis. In: Lee WHK, Kanamori H, Jennings PC, Kisslinger C (eds) International handbook of earthquake and engineering seismology, 81A, pp 437-451

Schluter RU, Fritsch J (1985) Geology and tectonics of the Banda arc between Tanimbar Island and Aru Island (Indonesia). Geol Jahrb 30:3-41

Silver EA, Reed R, McCaffrey R, Joyodiwiryo Y (1983) Back arc thrusting in the eastern Sunda arc, Indonesia: a consequence of arc continent collision. J Geophys Res 88(7429):7448. doi:10.1029/ JB088iB09p07429

Suzuki W, Aoi S, Sekiguchi H, Kunugi T (2011) Rupture process of the 2011 Tohoku-Oki mega-thrust earthquake (M9.0) inverted from strong-motion data. Geophys Res Lett 38:L00G16. doi:10.1029/ 2011 GL049136

Wang L, Shum CK, Simons FJ, Tassara A, Erkan K, Jekeli C, Braun A, Kuo C, Lee H, Yuan D-N (2012) Coseismic slip of the $2010 \mathrm{M}_{\mathrm{w}} 8.8$ Great Maule, Chile, earthquake quantified by the inversion of GRACE observations. Earth Planet Sci Lett 335-336:167-179. doi:10.1016/j.eps1.2012.04.044, ISSN $0012-821 \mathrm{X}$ 
Welc JL, Lay T (1987) The source rupture process of the great Banda sea earthquake of November 4, 1963. Phys Earth Planet Inter 45:242-254

Wells DL, Coppersmith KJ (1994) New empirical relationships among magnitude rupture length, rupture width, rupture area, and surface displacement. Bull Seismol Soc Am 84(4):974-1002

Wichmann A (1918) Die Erdbeben des Indishen Archipels Bis Zum Johpe 1857, (in Dutch), Koninkl. Nederlandse Akad. Wetensch. Verh. 2nd Sect. 20, 193 p 